Arnita A. Jones ${ }^{1}$

\title{
Organizing Public History
}

\author{
${ }^{1}$ Executive Director Emerita, American Historical Association, Washington, DC, USA, E-mail: arnitajones@gmail.com
}

DOI: $10.1515 /$ iph-2018-0005

With apologies to Charles Dickens, "It was the worst of times, it was the best of times."1 It was the mid-1970s, a time of misery and disappointment for hundreds of new PhDs in history in the United States, virtually all of them groomed for college and university teaching, and competing for far too few jobs. But it was also the beginning of public history as a field of graduate history education, a development that would revitalize both the teaching and the practice of the discipline and which continues to expand its horizons to the present day.

Public history came into my life in the spring of 1977 when I saw an advertisement in the AHA Newsletter announcing a search for a project coordinator who would staff a new initiative sponsored by the American Historical Association (AHA), the Organization of American Historians (OAH), and several regional and specialized history groups. ${ }^{2}$ The aim of this new effort was to address what had come to be considered a crisis in the employment market for new PhDs in history - a crisis fueled by unprecedented growth in the number and size of history doctoral education programs created as a part of the expansion of American higher education after World War II. By the mid 1970s, however, that growth in higher education had run its course, ending with a sharp drop in the need for new faculty in history and many other fields. The National Coordinating Committee for the Promotion of History (NCC), as the new effort was inelegantly named, was meant not only to identify and publicize existing employment opportunities for newly minted $\mathrm{PhD}$ historians in and around the academy, but also to explore what were called "non-traditional" positions or "alternative" careers as well. Curious, and in need of employment myself, I sent a letter of application to AHA's executive director Mack Thompson, landed an interview, and ultimately a job-the best job I ever had because, as it turned out, I had to invent it.

Other than the initial job advertisement for a Project Director of the NCC, there was little structure and budget for this position. I was provided decent but modest salary, a desk in a renovated bathroom on the top floor of the American Historical Association headquarters at 400 A Street on Capitol Hill in Washington, DC, and telephone numbers of several historians in the Washington area who had agreed to chair resource groups in possible employment areas like federal government, state and local government, business, and historic preservation. But what exactly was the problem? Too few jobs? Too many historians? Or historians insufficiently prepared for positions that might actually exist? A book on the shelves of the AHA library yielded a partial answer to the first two questions, and the contacts I had been given for the resource groups shed welcome light on the third.

The Education of Historians in the United States, published in 1962, was the work of an AHA Commission on Graduate Education in History, established in 1958 with support from the Carnegie Commission of New York to investigate issues of supply and demand for PhD historians in the near future. Under the leadership of Tulane University historian John Snell the Graduate Education Commission undertook a detailed examination of past production of history doctorates and projected likely needs for the near future, based on population trends. The resulting report was relatively conservative. It did not, for example, advocate for new outside sources of support for graduate study in history, recommending instead that some history departments not currently offering graduate education consider doing so, and calling on existing graduate programs to modestly increase their enrollments. ${ }^{3}$

Throughout the report, however, the focus was on the $\mathrm{PhD}$ as a preparation for college and university teaching, not careers in museums, corporations, archives, government agencies and elsewhere. The lesson it drew, for example, from considering an earlier era of unemployment of young historians during the Great Depression of the 1930s, was simple: "In 1939, probably no more than two-thirds of the history PhDs of 1931-35 were engaged in teaching in universities, colleges, and junior colleges but others would have been teaching if they could have found positions." ${ }^{4}$ Clearly the historical profession was not going to be prepared for what happened in the 1970s, when there were academic job openings for scarcely more than half of new doctorates. 


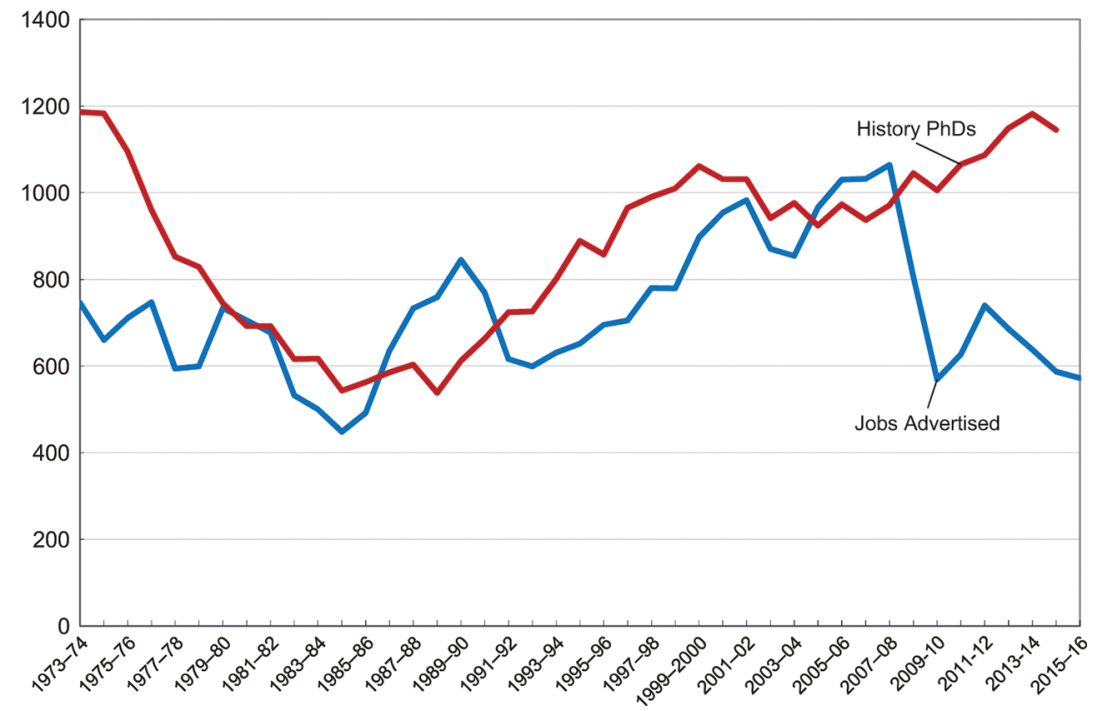

Figure 1: Number of new History PhDs and Advertised Job Openings 1974-75 to 2015-16. copyright: Trends in history PhDs tabulated from annual reports of the federal Survey of Doctorate Recipients. Data on job openings are counts of jobs advertised in publications of the American Historical Association (the Employment Information Bulletin and later Perspectives on History). Data analyzled and presented by the American Historical Association. Originally found in Robert B. Townsend and Emily Swafford, "Conflicting Signals in the Academic Job Market for History," Perspectives on History, January 2017, 27.

\section{Public History Emerges as a Field of Study and Practice}

Conversations with NCC resource group chairs proved more heartening than my review of earlier efforts to address dysfunctional job markets for historians. If in the beginning the National Coordinating Committee represented not so much a clear plan as a heartfelt intention on the part of leaders in the participating organizations to do something, what it soon became was a network of concerned historians in government agencies, scholarly societies, and graduate programs who were glad to gather and share information on the kind of work they and other historians were already doing. Important among these early advisors were Richard Hewlett, Chief Historian in the Atomic Energy Commission; Richard Baker, Historian of the U. S. Senate; Robert Pomeroy in the Inter-American Development Bank; David Trask, State Department Historian; Suellen Hoy of the Public Works Historical Society; David Clary of the U.S. Forest Service; Larry Tise, Director of the North Carolina Division of Archives and History; Barbara Howe, an Ohio Preservation Officer and faculty member of Heidelberg College, and Harvard University historian Ernest R. May who was one of the creators of the Careers in Business program, a highly publicized effort to train and place humanities doctorates in corporate jobs related to their skills and education. Among this group were five who later became founders of the National Council on Public History. $^{5}$

Institutional networks were also important in those days before electronic communication was routine or even possible outside the scientific community. The American Historical Association had several hundred institutional members, offering a window into what was going on within history departments, while foundations - particularly the National Endowment for the Humanities (NEH) and the Rockefeller Foundation were also an important source of information about new programs. It was, in fact at a meeting on humanities careers hosted by the NEH in Washington early in my tenure at the NCC that I first met Wesley Johnson of the University of California, Santa Barbara (UCSB). He was reporting there on the public history program at UCSB, which had received substantial support from NEH as well as the Rockefeller Foundation, while I described the efforts of the National Coordinating Committee to identify new training programs and new kinds of careers for historians. Those present seemed to be reasonably impressed with my description of the history organizations' efforts to counter the job crisis but Johnson mesmerized the audience with his vision of a different kind of future for graduate work in history. At the end of the day I too wanted to learn more about public history and the program at UCSB but Wes had a plane to catch, so he encouraged me to telephone his colleague Robert Kelley in Santa Barbara. I did, and after a few hours of conversation with Kelley that ran into the evening, I understood that public history could not only offer real help to young historians entering the job market - it could alter the discipline of history itself. ${ }^{6}$ 


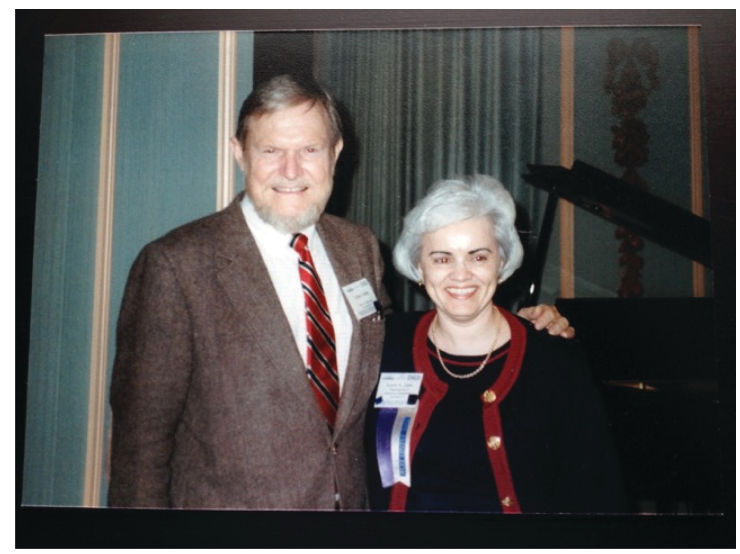

Figure 2: Arnita Jones and Robert Kelley. Organization of American Historians Meeting, St. Louis, 1989.

According to Wesley Johnson, the name Public History was the creation of Robert Kelley, an Air Force veteran who had served in both World War II and the Korean War, initially as a bombardier but later as an administrator and a historical officer. ${ }^{7}$ After receiving his doctorate in history from Stanford University, Kelley served as a civilian historian in the headquarters of the Air Defense Command before joining the history department at the University of California, Santa Barbara. There he pursued not only a typical university career of research and writing but also served as a consultant to state government in California, undertaking litigation research, and testifying as an expert witness in cases relating to water rights. It was from this experience that Kelley began to formulate the idea that historians had much to offer the wider community in serving the research needs of policy and decision makers. ${ }^{8}$

It is important here to remember that historians had practiced their craft in museums, historical societies, government offices and other kinds of institutions long before the employment crisis experienced by historians in the 1970s, but this practice did not seem to need a separate name. Public history as we think of it today had never been a focus of history graduate education programs which, as we have seen, were traditionally centered on training college and university faculty. The practice of history outside the academy simply had no name and was not a subject of interest in the training of historians. Neither did the content of its work seem to require any special attention on the part of university-based graduate education. The American Historical Association, founded in 1884, was originally a broad-based organization that included many for whom history was an avocation rather than a livelihood, but after a few decades its focus narrowed more towards teaching and academic research. ${ }^{9}$ In the early twentieth century, for example, historians at state and local historical societies had developed sufficient strength within the larger profession as represented by the AHA to form within it their own Conference of Historical Societies. As the number of historical societies from grew substantially between the two world wars, the relationship continued to erode, ending finally in 1940 with a break that resulted in the formation of a new American Association for State and Local History. ${ }^{10}$ Similarly, with a rapidly growing number of state and local archives established over the first half of the twentieth century and a new National Archives approved by Congress in 1934, professionals working in these fields also found their interests insufficiently recognized within the AHA and departed in 1935 to form the Society of American Archivists. ${ }^{11}$

In this context what had seemed like a disaster in the early 1970s was beginning to appear more like an opportunity because - absent the job crisis - it is highly unlikely that a new kind of graduate training that challenged the existing institutional infrastructure would have been welcomed by higher education institutions. But because there were so many fewer academic positions for the graduates of traditional history programs these clearly could not be sustained at the level at which they had previously existed. Some history departments cut back sharply in admitting students to their programs but others reached out to former students, to take advantage of their experience in, yes, alternative careers. Academic historians responsible for managing graduate programs became more prepared to look into the experience of the few programs in graduate and applied history that had sprung up around the country and consider what might fit their own institutions.

What also made a substantial difference at this point is that the two largest historical organizations in the U.S. were led by individuals - Richard Kirkendall, who was the Executive Secretary of the Organization of Americans and Mack Thompson, Executive Director of the American Historical Association Historian - who understood early that a healthy profession could not be sustained without addressing demographic realities and that the future of the discipline might require being open to creative solutions. It was these two groups that in the late 1970s provided primary support to the National Coordinating Committee and encouraged it to become a network for gathering and sharing information about a new field of history. 
The times, so inauspicious in some ways, were an advantage in others. In 1976 a new President of the United States, Jimmy Carter, filled the leadership of federal government cultural and educational agencies with officials who were inclined to open the cultural programs of the federal government to a wider public. ${ }^{12}$ Critical in this effort was the appointment of Joseph Duffey as head of the National Endowment for the Humanities $(\mathrm{NEH})$. Duffey, who had pursued a career in academic and nonprofit administration as well as politics, brought to his appointment as NEH Chair a strong conviction that humanities scholarship and teaching were as important in community colleges as in the most prestigious universities, that debates over public policy issues could be informed by the research of historians and scholars from other humanities disciplines and that humanities scholarship should be open and available to the widest range of the American people as possible. Under his administration the state humanities councils were expanded and encouraged while NEH staff and outside reviewers of proposals represented a wider range of institutions as well. As we shall see state humanities councils became an important source of funding for public history projects, including those that helped to build the structure that was to become the National Council for Public History. ${ }^{13}$

Equally important to public history was the Rockefeller Foundation, which in 1974 named Joel Colton, a historian of modern France who had served in military intelligence during the World War II, to head its recently revived humanities division. Under his leadership the Foundation supported a national commission that explored the role of the humanities in public life and provided partial support both to the National Coordinating Committee and the Public History Program at UCSB. Colton's tenure at Rockefeller has been described as "characterized by a commitment to humanities scholarship, public engagement, and a firm belief in the humanities' relevance to public discourse." 14

The NEH and the Rockefeller Foundation did not create public history, any more than did the National Coordinating Committee for the Promotion of History housed on Capitol Hill at the American Historical Association. But what these organizations made possible was an interlocking set of national networks that could tap into existing institutions and organizations to marshal resources for meetings, newsletters, and eventually a journal, The Public Historian. Together these resources afforded emerging public history programs the opportunity to share experiences and learn from each other, as well as access to a national audience of historians who, buffeted by challenges faced by higher education in the late 1970s, were increasingly receptive to new ideas about the training of historians and the role of historians in society. Eventually the consortium of historical associations that comprised the National Coordinating Committee was able to sponsor not only resource groups in discrete employment areas but also to organize committees in a number of states focused on encouraging and exploring a wider variety of careers for historians and it was often that these kinds of efforts were supported by one of the NEH state humanities councils.

\section{Public Historians Organize: The National Council on Public History}

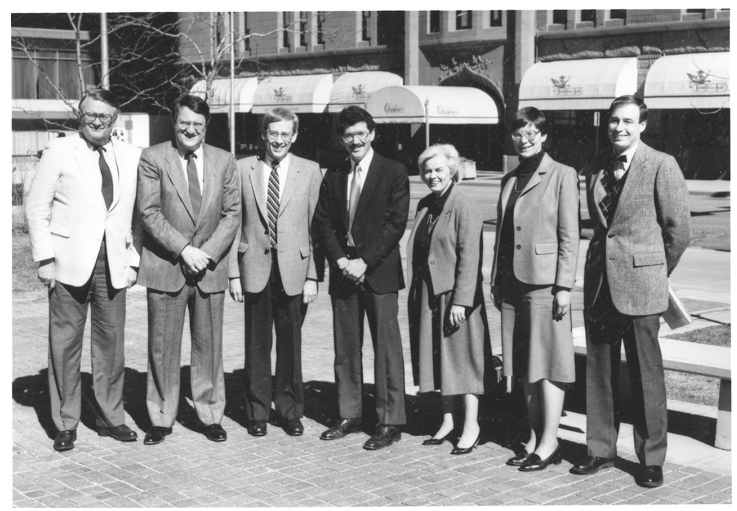

Figure 3: Early Chairs of the National Council on Public History, at Denver, Colorado, NCPH meeting, 1988. (from left to right: Wesley Johnson, Larry Tise, Noel Stowe, Michael Scardaville, Arnita Jones, Barbara J. Howe and Ted Karamanski). copyright: National Council on Public History.

It did not take long for public historians to begin to create a national organization that would serve the interests of this new field, and they had help. In 1978 the Arizona State Humanities Council supported a short conference on public history at Arizona State University that brought together a number of practitioners, representatives of interested history departments, and other history organizations. The following year both NEH and the Rockefeller Foundation supported the national conference of public historians at Montecito, California that began the formal process of creating a permanent organization: the National Council on Public History. ${ }^{15}$ 
Both the American Historical Association and the Organization of American Historians as well as other historical groups were generous in making space available in the pages of their newsletters or on the programs of their annual meetings to publicize developments in the field of public history. With access to the AHA's institutional database - largely, but not entirely academic history departments in universities - the NCC was able in 1978 to survey 1800 history departments about new initiatives for preparation of students for careers outside of teaching, or internships that would broaden their experience. The results included a handful of older programs focused on historic preservation but forty-five other programs that were no more than two years old, while other history departments responded that they were considering new programs. Some focused on archives, others emphasized applied and policy research, while most centered on cultural resource management and/or historic preservation. More descriptive than prescriptive, the survey results helped define the field at that time, both facilitating and encouraging interaction among public historians. ${ }^{16}$

That same year the AHA was also instrumental in supporting an NCC survey of historical programs in the U.S. federal government that was used to compile a Directory and Survey of Historical Offices and Programs in the Federal Government. Published and distributed by the American Historical Association in 1978 the Directory listed 118 historical units in cabinet level departments and agencies throughout the national government. Generous with their time and wise in their advice, these experienced federal historians who collaborated with the NCC were an invaluable resource for new public history programs. Out of this effort ultimately came a second new public history organization, the Society for History in the Federal Government (SHFG), founded in Washington in $1979 .{ }^{17}$

While the creation of an organization for historians and contractors engaged in archival and historical work for the federal government was a great step forward, it was clear that public historians required a broader and somewhat different organization as well. To that end a steering committee had been established at the Montecito, California, meeting in early 1979 and was charged with exploring the feasibility of creating an organization to serve the needs of public historians. The committee used the occasion of a federal historians' conference the following September to continue their deliberations. As the federal historians meeting broke up in the late afternoon, the steering committee reconvened in the National Archives building and officially organized a National Council on Public History (NCPH). As it happened, then, the two major public history organizations were founded in the same city at the same time. ${ }^{18}$

Wesley Johnson of the Santa Barbara public history program and editor of its journal, The Public Historian, agreed to become acting chairman of the steering committee. Early on, there were debates about the name (public or applied history), and the governance structure (a council or a membership organization), but eventually those present agreed to establish a set of committees to explore these issues and make recommendations about the structure and financing of this new organization at a conference planned for the following April in Pittsburgh, to be hosted by Carnegie-Mellon's applied history program. To this day there is argument about who proposed the source of financial support that would sustain the new organization but eventually it was decided that the thirty-two members of the Council would each write annual $\$ 100$ checks. Though in the years that followed there were grants and institutional support of one kind or another from university programs as well as NEH and the foundations, $\$ 100$ checks from board members were necessary until 1987. Wesley Johnson was the first chair of the new National Council on Public History, while Robert Pomeroy of the Inter-American Development Bank and chair of NCC's Business Resource Group subsequently offered his address as the location for incorporation of the new organization in the District of Columbia and also became its first Treasurer, serving in that post until $1984 .{ }^{19}$

As the field of public history and the NCPH grew, additional staffing soon became necessary. Philip Cantelon, who had been a contractor at the Department of Energy's history office and was a founder and CEO of History Associates Incorporated, one of the first history consulting companies, agreed to serve as an unpaid interim executive director in 1981. Leaders of the NCPH also began to plan for the long-term future of the organization, and commissioned a study by Anna Nelson, who had developed a graduate history and policy program at George Washington University. Her report for NCPH highlighted the need for a more permanent headquarters and staff if the NCPH was to reach its potential. ${ }^{20}$

Following Anna Nelson's recommendations, the NCPH was in 1984 able to establish an organizational structure quite similar to what it retains today. Barbara Howe, then a faculty member in the West Virginia University's public history program was afforded release time by the University to serve as Executive Director with responsibility for managing the Council's business and other operations housed in the history department there. The NCPH moved to a similar situation at Northeastern University in 1987, until its relocation at Indiana University-Purdue University (IUPUI) in Indianapolis, where it remains today. ${ }^{21}$ 


\section{Public History Coes International: The International Federation for Public History}

As NCPH began its fourth decade it seemed clear that public history was firmly established in the United States and had begun to flourish in other parts of the world as well-particularly in the English-speaking countriesAustralia, New Zealand, Canada and the United Kingdom. In the early 1980s the indefatigable Wesley Johnson, managed to secure funding from the Rockefeller Foundation, NEH, and the United States Information Agency (USIA) to attend meetings and lectures in Britain, France, Germany, and Italy, as well as a public history conference at Erasmus University in Rotterdam and a seminar on public history at the Ecole Normale Superieure in Paris. ${ }^{22}$

In any case, however, was not until 2009 that sufficient interest in international public history developed to persuade the NCPH governing board to establish an Ad Hoc International Task Force to "reinforce NCPH's connections with a growing number of public historians worldwide." ${ }^{23}$ That same year, a Conference on "Public History in Germany and the United States" was held in Berlin, co-sponsored by the Free University of Berlin and the German Historical Institute in Washington, DC. ${ }^{24}$ On the cusp of retirement from the American Historical Association, I had been pleased to be invited to the conference and was greatly encouraged by the energy and enthusiasm for public history among its participants. My schedule for that trip also included representing the AHA at a meeting in Rome of the Comité International des Sciences Historiques (CISH) ${ }^{25}$ This venerable international association of historical organizations had been formed in The Hague in 1898 but was temporarily a casualty of the First World War. Revived in 1923, as an effort to re-establish contacts between scholars across formerly hostile borders, CISH has national committees (the AHA is the national committee for the US) and also special interest groups representing particular fields such as military or women's history. Because one of the items on the CISH meeting agenda in 2009 was the need to attract historians from newer fields, there was great interest in hearing about public history and the Conference in Berlin I had just attended. From there it was but a short step to an enthusiastic discussion about the creation of an Internal Commission on Public History under the CISH umbrella. ${ }^{26}$

Over the next several months the NCPH International Task Force led by Anna Adamek of the Canada Science and Technology Museum worked on a proposal to CISH for a new internal commission which we named the International Federation for Public History, with the NCPH headquarters as its permanent address, and English and French as its official languages and the following goals:

1) to create an international network of public history programs and scholars

2) to share recommended professional and academic best practices

3) to foster participation of public historians in international congress and other meetings and

4) to encourage the formation of national committees of historians working in the field of public history

Since I was scheduled to represent the American Historical Association at the next International Congress of Historical Sciences in Amsterdam in 2010 it was efficient for me to present the application of the IFPH to the International Congress of Historical Sciences where it was unanimously and enthusiastically accepted. Shortly thereafter Anna Adamek proposed that the NCPH's International Task Force begin planning for an organizational meeting and election of officers of the new organization the following spring at the next NCPH annual meeting in Pensacola, Florida. ${ }^{27}$

Thirty-eight historians attended a founding meeting convened by an interim steering committee of the International Federation for Public History held during the annual meeting of the NCPH in Pensacola, Florida in April of 2011. ${ }^{28}$ There was much work to be done, including a review and revision of the initial by-laws, establishment of nominating committee to suggest candidates for a permanent steering committee, and consideration of opportunities for participating in the 2015 conference of the International Congress of Historical Sciences in Jinan, China. ${ }^{29}$

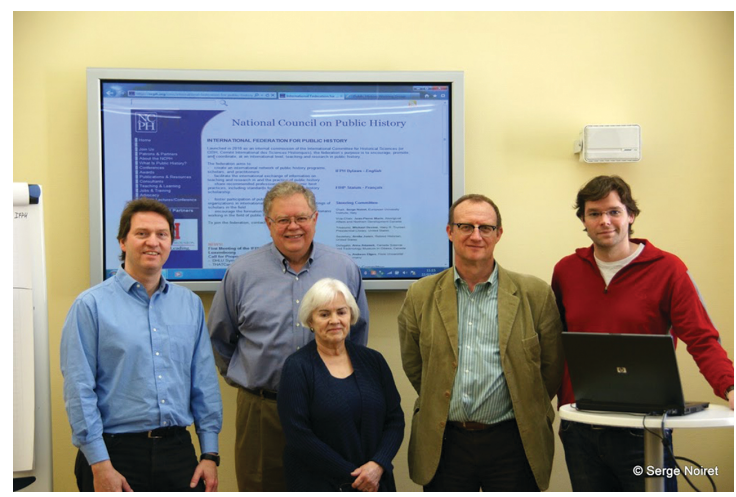


Figure 4: First Steering Committee, International Federation for Public History, Luxembourg, 2012. (from left to right: Andreas Etges, Michael Devine, Arnita Jones, Serge Noiret, Jean-Pierre Morin). copyright: Serge Noiret.

Early in 2012 the IFPH had elected a Steering Committee which included Serge Noiret, European University Institute, Italy, as Chair; Jean-Pierre Morin, Aboriginal Affairs and Northern Development Canada, Vice-President; Michael Devine, Truman Presidential Library, United States, treasurer; Arnita A Jones, American Historical Association, emerita, corresponding secretary, United States; Anna Adamek, Canada Science and Technology Museum, Canada and Andreas Etges, Free University of Berlin, Germany. In Luxembourg, as guests of the Centre Virtuel de la Connnaissance sur l'Europe (CVCE) which was hosting a Digital Humanities Symposium in Luxembourg, the new Steering Committee was able to present the new organization in a public meeting and also complete the basic organizing work that was needed for IFPH to begin operation. A joint meeting with NCPH followed later that year in Milwaukee, Wisconsin, and in 2014 in Ottawa, Canada. A first independent conference was convened in Amsterdam, the Netherlands, in 2014 while the next year several sessions were sponsored by IFPH during the meeting of the International Congress of Historical Sciences (CISH) in Jinan, China in 2015.

The International Federation for Public History was on its way.

\section{Conclusion}

What's in a name? Why did we need the term public history? How is it that we have more than one organization that uses the label? My recollection is that in discussions leading to the founding of the IFPH there was an early consensus about using the phrase "public history" to describe the new international organization, leaving possible future national organizations to develop their own terminology, depending on practice and the nuance of individual languages. Public history is a useful and appropriate name because it always implies a willingness to reach out to engage audiences in conversations about historical research, even if that research involves contentious issues like the displacement of statues and memorials relating to the ending of American slavery, a new holocaust museum in Poland, or dueling versions of the exploitation of "comfort women" during the Japanese invasion of Korea during World War II. Names are also important in the creation of communities even, or perhaps especially, communities like the International Federation for Public History, where historians engaged with the public depend on having the opportunity to learn from each other by sharing experiences across different kinds of borders.

The early growth of public history in the United States in the 1980s and 1990s took place during a period characterized as the American culture wars, fraught with quarrels about marking the 50th anniversary of the use of atomic bomb in Japan, the content of learning standards for U. S. and World History and a host of other issues. It was a time when historians were often vilified as "politically correct" or partisan. Those doing public history work soon came to realize that the profession's standards of research, interpretation and writing which had developed over several generations in and outside of the academy cannot be taken for granted and must be zealously defended. To that end the field needed the support offered by the older and larger professional associations in history, particularly the AHA and the OAH. The incubation space these groups provided was particularly welcome as it made possible the growth of networks for sharing and discussing issues arising from the teaching and practice of public history.

Public history has also significantly altered the wider historical profession in the United States, as the field's research and practice have been included in scholarly journals and other publications, and as traditional professional organizations have embraced long-term initiatives that are squarely in the realm of public history practice, Two decades ago the $\mathrm{OAH}$, for example, responded enthusiastically to an initial overture from Dwight Pitcaithley, then Chief Historian of the U. S. National Park Service, who offered a "cooperative agreement" through which the Parks could regularly secure help from college and university historians by engaging them in theme studies, administrative histories and other efforts to "ensure that the American public receives current, nuanced, and thought-provoking information about the nation's past." That agreement and working arrangement continue today. ${ }^{30}$ In the early years of the twenty-first century the AHA, located in the capital city of Washington, DC, established a National History Center "to reinforce the critical role that history and historical knowledge play in public decision-making and civic life." Chief among these efforts are Congressional Briefings that provide historical background on legislative issues likely to come before the U.S. Senate and House of Representatives, as well as a Washington History Seminar in cooperation with the Smithsonian Institution's Woodrow Wilson Center that regularly brings together scholars with government officials, policy and opinionmakers and others to consider new historical research that can inform public policy. ${ }^{31}$ 
Ironically, however, in the United States the future of history in the academy seems problematic, for during the several decades that public history has grown and flourished, history enrollments in many colleges and universities have continued to decline, even as the percentage of tenured faculty among the professoriate continues to shrink. In a recent editorial in The American Historian, outgoing OAH President Edward Ayers lamented the current position of history in American higher education: "Historians worry about our discipline. Graphs and tables confirm what we all feel -that we are losing students and majors, that jobs are declining in numbers and security, that our relative position within colleges and universities is waning."

Yet Ayers, former college president, academic dean, and leader of one of the earliest history projects to take advantage of opportunities afforded by the use of digital technology, ${ }^{32}$ describes as promising the current environment in view of the many public history opportunities historians are exploring. I agree. Colleges and universities looking to develop a stronger relationship with their communities, supporters, and potential students will find the tools and habits of mind of public historians to their advantage. By the same token, for public historians to fulfill their potential, there will always be need for rigorous training in historical research and writing that can best be done by colleges and universities. This relationship between higher education and public history requires continual nurturing, a need that NCPH, The Public Historian, IFPH, and the new International Public History are well-positioned to address.

\section{Notes}

1 Charles Dickens, A Tale of Two Cities (London: Chapman \& Hall, 1859).

2 Founded in the United States in 1884, the AHA is the oldest and largest professional organization serving historians in all fields and professions. The OAH was founded as the largest professional society dedicated to the teaching and study of American history.

3 Dexter Perkins and John L. Snell, The Education of Historians in the United States (New York: McGraw-Hill, 1962), 35, $200-212$.

4 Ibid., 21.

5 Barbara J Howe, "Reflections on an Idea: NCPHs First Decade, The Public Historian 11.3 (1989), note 21. For more information about the "Careers in Business" program see Jonathan D. Ratner, "Program to Ready Ph.D.s For Careers in Business," The Harvard Crimson, 4 November 1977, accessed 12 April 2018, https:/ /www.thecrimson.com/article/1977/11/4/program-to-ready-phds-for-careers/

6 The first issue of The Public Historian, in fall 1977, provides a good survey of the origins of the field and its various areas of practice at that time. See especially G. W. J. [G. Wesley Johnson], "Editor's Preface," 4-10, Robert Kelley, "Public History: Its Origins, Nature and Prospects," 16-28, and Arnita Jones “The National Coordinating Committee: Programs and Possibilities," 49-60.

7 Private communication with Wesley Johnson, NCPH Annual Meeting, Providence, RI, 2009.

8 Jason H. Gart, "Robert Lloyd Kelley," American National Biography online, Oxford University Press, 2018; also Robert Kelley, "Proposal: Creating a New Professional Person: The Public Historian," undated manuscript in possession of Arnita Jones.

9 Robert B. Townsend, History's Babel: Scholarship, Professionalization, and the Historical Enterprise in the United States, 1880-1940 (Chicago: The University of Chicago Press, 2013). See especially Part III: "Scattering the Historical Enterprise 1926-40, 133-166.

10 Townsend, History's Babel, 49 Figure 2.1; Michael C. Scardaville, "Looking Backward Toward the Future: An Assessment of the Public History Movement," The Public Historian, 9.4, (Fall 1987), 34-43. See also Rebecca Conard, Benjamin Shambaugh and the Intellectual

un of Public History (Iowa City: Iowa University Press, 2002), on the fraying of connections between the large historical society of the Midwest and the Mississippi Valley Historical Association, which later became the Organization of American Historians.

11 Townsend, History's Babel, 159-62.

12 The 1980 report of the Commission on the Humanities is a good source for understanding the issues faced by the agency during these years: The Humanities in American Life: Report of the Commission on the Humanities. (Berkeley: Univ. of Calif. Press, 1980). http://ark.cdlib.org/ark:/13030/ft8j49p1jc/

13 In 1979 I was recruited from my position at the AHA staffing the National Coordinating Committee to become a program officer in the Office of Planning and Policy Assessment at the NEH and remained in that position until 1984.

14 "Joel Colton, "Rockefeller Foundation: A Digital History, Rockefeller Foundation President John H. Knowles, https://rockfound.rockarch.org/biographical/-/asset_publisher/6ygcKECNI1nb/content/joel-colton?inheritRedirect = false\&redirect = https \%3A\%2F\%2Frockfound.rockarch.org\%2Fbiographical\%3Fp_p_id\%3D101_INSTANCE_6ygcKECNI1nb\%26p_p_lifecycle\%3D0\%26p _p_state\%3Dnormal\%26p_p_mode\%3Dview\%26p_p_col_id\%3Dcolumn-1\%26p_p_col_pos\%3D3\%26p_p_col_count \%3D. Larry Kramer, "Joel Colton (1918-2011) Historian of France and Coauthor Textbook on Modern History," Perspectives in History 49.8 (November 2011). 15 The best account of the founding and early years of the National Council on Public History is by Barbara J. Howe, "Reflections on an Idea: NCPH's First Decade." The Public Historian 11.3 (Summer, 1989) 69-85.

16 Arnita A. Jones "Clio Confronts Adam Smith: A Survey of National Trends in the Adjustment of Training Programs for Historians." In Widening the Scope of the Profession, Papers and a Commentary Presented at a Meeting of the Southern Historical Association, 9 November 1978, OAH Newsletter (January 1979).

17 For further information about the history, publications and current programs of the Society for History in the Federal Government see its website at SHFG.org.

18 See Howe, Reflections on an Idea, 71-74.

19 Pomeroy was also the creator of its "Careers for Graduates in History" that was widely distributed (more than 100,000 copies) by the American Historical Association, the NCPH, history departments and other organizations in the 1980s. Howe, Reflections on an Idea, 78. 


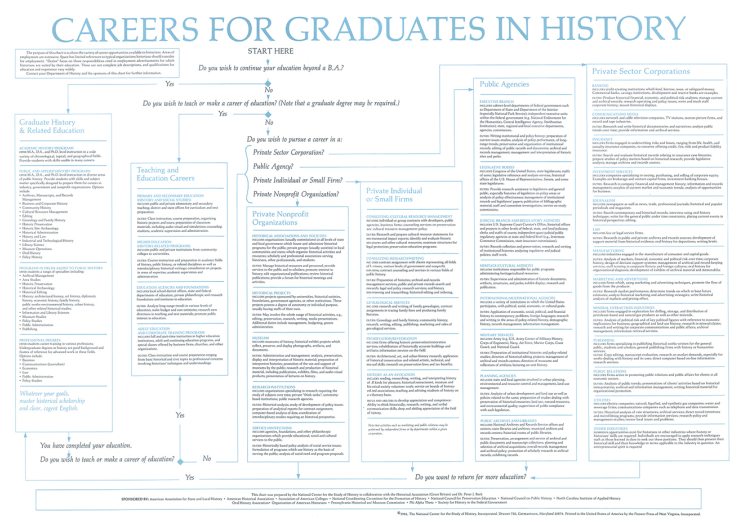

Figure 5: Careers for Graduates in History.

copyright: The Careers for Graduates in History Chart is reprinted with the permission of Robert Pomeroy and Philip Cantelon, formerly director of the National Center for the Study of History.

20 Private conversations and correspondence with Philip Cantelon and Barbara Howe; spring 2018. See also Philip L. Cantelon, “The Society for History in the Federal Government: Twenty-Five Years Later," The Federalist No. 1 (Spring 2004), 3, 4.

21 Howe, Reflections on an Idea, 10. See also the NCPH history page at http://ncph.org/about/our-history/

22 G. Wesley Johnson, Jr., "An American Impression of Public History in Europe," The Public Historian 64 (Fall, 1984), 87-97. Jannelle Warren-Findley also undertook similar missionary efforts on behalf of public history in Australia, and New Zealand, where a robust public history community developed in the 1990, when talk of an international task force began to be discussed. Jannelle Warren-Findley, "The Globalizing of Public Practice: A Personal Journey," The Public Historian 20.4 (Fall 1998) 11-20.

23 Marianne Babel, “Planning Ahead," Public History News 20.1 (December 2009), 10.

24 Anke Ortlepp, "Public History in Germany and the United States: Fields, Developments and Debates in Praxis and Theory," Bulletin of the GHI 45 (Fall 2009), 122-127.

25 The preferred use of the name seems to be in French but the English version is International Congress of Historical Sciences (ICHS).

26 Arnita A. Jones, “Creating the International Federation for Public History," Public History News 31.1 (December 2010), 1-4.

27 Note: John Dichtl to NCPH International Task Force, September 14, 11 February 2010, 2011; see also Anna Adamek, chair, "International Task Force" in Committees on the Go, Public History News, 31.1 December 2010, 8 and also Anna Adamek to NCPH International Task Force correspondence between John Dichtl, Anna Adamek, and Arnita Jones, 20 September 2010.

28 NCPH Executive Director John Dichtl to IFPH Steering Committee, 15 April 2011; Dichtl also reported that the IFPH list by then included 66 people from 12 countries, including Australia, Bangladesh, Canada, Germany, Italy, Jamaica, Luxembourg, the Netherlands, New Zealand, Singapore, the United Kingdom and the United States.

29 Minutes, IFPH Meeting, Pensacola, 8 April 2011.

30 Organization of American Historians collaboration with the National Parks: http://www.oah.org/programs/the-oah-national-parkservice-collaboration/

31 National History Center, American Historical Association http://nationalhistorycenter.org/about/programdescriptions/washington-history-seminar/

32 Edward L. Ayers, "The Possibilities of American History," The American Historian 15 (2018) 1-2. 